\title{
Prevalence and intensity of Streblidae in bats from a Neotropical savanna region in Brazil
}

\author{
Ludmilla M. S. Aguiar ${ }^{1,2}$ and Yasmine Antonini ${ }^{3}$
}

\author{
${ }^{1}$ Programa de Pós-Graduação em Zoologia, Departamento de Zoologia, Instituto de Ciências Biológicas, Universidade de Brasília, \\ Brasília, DF, Brazil; \\ ${ }^{2}$ Programa de Pós-Graduação em Ecologia, Departamento de Zoologia, Instituto de Ciências Biológicas, Universidade de Brasília, \\ Brasília, DF, Brazil; \\ ${ }^{3}$ Programa de Pós-Graduação em Ecologia de Biomas Tropicais, Departamento de Biodiversidade, Evolução e Meio Ambiente, \\ Instituto de Ciências Exatas e Biológicas, Universidade Federal de Ouro Preto, Ouro Preto, MG, Brazil
}

\begin{abstract}
Bats of the family Phyllostomidae are common hosts to streblids known as bat flies. Here, we discuss the component community, prevalence and intensity of infection with species of Streblidae on an assemblage of phyllostomid bats in the Cafuringa Environmental Protection Area (APA Cafuringa) in the core area of the Cerrado in Central Brazil. A total of 1841 streblid individuals of 24 species occurred on 752 bats of 14 species. Ten species of streblids infected Glossophaga soricina (Pallas), whereas seven or fewer streblid species infected the other bat species. Nine bat fly species presented a prevalence of more than 50\%, whereas some differences in the abundance of bat flies among hosts were observed. Strebla wiedemanni Kolenati, 1856 and Trichobius furmani Wenzel, 1966 were more host-specific compared to the other streblids, and they occurred in greater abundance on their preferred hosts. Trichobius uniformis Curran, 1935 and Strebla mirabilis (Waterhouse, 1879) were the least host-specific, occurring on five and six hosts, respectively.
\end{abstract}

Keywords: Diptera, ectoparasites, Chiroptera, Cerrado, South America

Bat flies, i.e. species of the family Streblidae (Diptera: Hippoboscoidea) are obligate ectoparasites of Chiroptera (Dick and Patterson 2006) and are typically associated with bats of the family of Phyllostomidae (Dittmar et al. 2006). Phyllostomid bats are unique to the New World, with the majority of species found in tropical and subtropical regions (Whitaker 1988). Streblids may possess normal, reduced or no wings. Their eyes may be small or absent and their bodies may be laterally or dorsoventrally flattened, with legs that can be short and robust or long and thin (Whitaker 1988).

Azevedo and Linardi (2002) reported that few data about streblid flies are available in Brazil. Several studies have been published but mainly from the Atlantic Forest (França et al. 2013), which is one of the five Brazilian biomes. As noted by Bertola et al. (2005), several studies have been conducted on the taxonomy of Streblidae, but only a few explored host-parasite relationships.

Seventy species belonging to 20 genera of streblid bat flies are registered in Brazil (Graciolli et al. 2010, Graciolli and Azevedo 2011). However, these numbers certainly underestimate the real richness of bat flies (Dias et al. 2009,
Graciolli et al. 2010). In fact, more than $90 \%$ of the vast Brazilian territory has not being properly surveyed for bats (Bernard et al. 2011). Consequently, reports on their ectoparasites are even more rare, and if the real richness of bat flies is unknown, then the relationship between bat flies and their hosts is probably in the same category.

The parasitism of streblids may be affected by some factors intrinsic to the bat hosts, such as body size, grooming behaviour and immunological defences (Ter Hofstede and Fenton 2005, Patterson et al. 2007, 2008). Furthermore, the different types of bat roosts and the sharing of roosts among individual bats and among different bat species are known to affect the distribution and abundance of streblids on the host populations (Patterson et al. 2007). From another point of view, the knowledge of bat ectoparasites provides valuable information about the biology, systematics, and phylogeny of the host (Fritz 1983).

Host specificity is typical for parasite-host associations. Obligate or permanently present parasite associations are usually higher (Dick et al. 2009) and, therefore, ectoparasites can be classified as heteroxenous, which is when they can infect many species in many genera. The term mon-

Address for correspondence: Y. Antonini, Programa de Pós-Graduação em Ecologia de Biomas Tropicais, Departamento de Biodiversidade, Evolução e Meio Ambiente, Instituto de Ciências Exatas e Biológicas, Universidade Federal de Ouro Preto, Ouro Preto, MG, Brazil. E-mail: antonini.y@gmail.com 

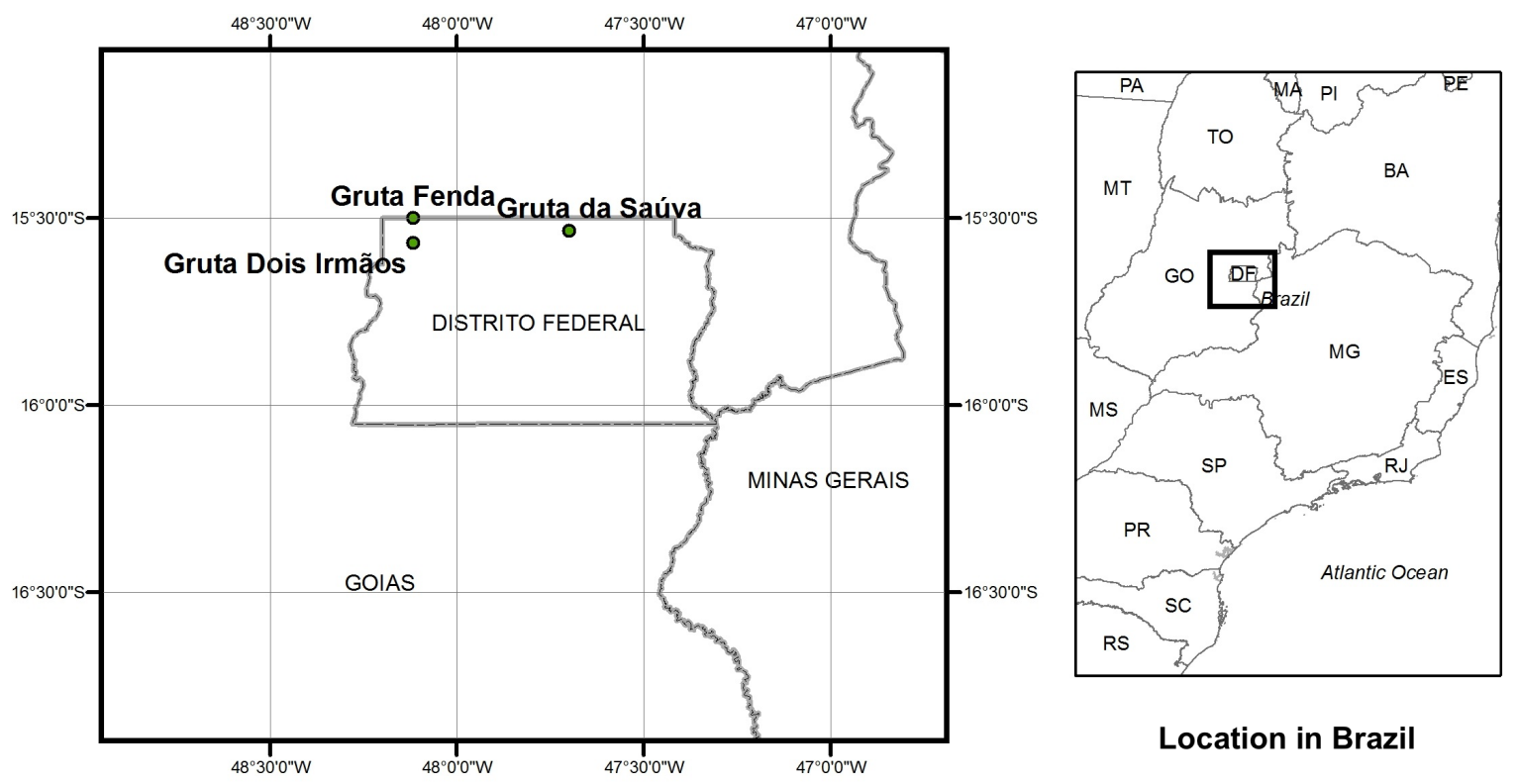

Fig. 1. Map of the caves of the Cafuringa Environmental Protection Area in the Cerrado of the Federal District, Brazil.

oxenous describes ectoparasites found on only one host species. When the ectoparasites are on two or more host species of the same genus, they are stenoxenous, and when they are regularly established on hosts belonging to different genera, they are oligoxenous (Ter Hofstede et al. 2004).

For the Cerrado region of Brazil, there are only five studies that report quantitative parasitological indices for the streblid communities (Coimbra et al. 1984, Komeno and Linhares 1999, Aguiar and Antonini 2011, Eriksson et al. 2011, Santos et al. 2013). Herein, we present a study about the component community, prevalence and the intensity of a infection of Streblidae on a bat assemblage (Phyllostomidae) present in the Cafuringa Environmental Protection Area (APA Cafuringa) in the core area of the Cerrado biome, a Neotropical savanna. The purpose of this paper was to study host-parasite relationships, evaluating the degree of variability in the streblid distribution in the different host populations.

\section{MATERIALS AND METHODS}

\section{Study area}

We captured bats monthly from April 2004 to March 2005 in three caves with 90 to 773 metres of horizontal development in the interfluvial mesophytic forests within the Cafuringa Environmental Protection Area (CEPA). The CEPA is located northwest of Brasília $\left(15^{\circ} 30^{\prime}-15^{\circ} 40^{\prime} \mathrm{S}\right.$; $\left.47^{\circ} 50^{\prime}-48^{\circ} 12^{\prime} \mathrm{W}\right)$ and is a 46000 ha area characterised by karst geomorphology with steep and dry relief (Fig. 1). The climate of the region is characteristic of the Cerrado biome, with a dry winter and a rainy summer, and it is classified as Aw Köppen (Alvares et al. 2013).

\section{Collection and identification of ectoparasites}

Streblids flies were collected from bats captured with mist nets placed near the entrance of the following three caves (Fig. 1): Saúva is a dry limestone cave $\left(15^{\circ} 32^{\prime} \mathrm{S} ; 47^{\circ} 42^{\prime} \mathrm{W}\right)$ with $235 \mathrm{~m}$ of development, having three parallel segments connected by secondary conduits. It is poorly ventilated and can be accessed only by a small entrance. The external vegetation is mainly gallery forest. Dois Irmãos is a dry limestone cave $\left(15^{\circ} 34^{\prime} \mathrm{S}\right.$; $\left.48^{\circ} 07^{\prime} \mathrm{W}\right)$ with $90 \mathrm{~m}$ of development, consisting of several small rooms at two superimposed levels and one entry. It is placed on a limestone hill covered by a mesophytic interfluvial forest and surrounded by savanna and crops. Fenda is the largest granite cave $\left(15^{\circ} 30^{\prime} \mathrm{S}\right.$; $\left.48^{\circ} 10^{\prime} \mathrm{W}\right)$ in the Distrito Federal, located at $840 \mathrm{~m}$ above sea level. It has $341 \mathrm{~m}$ of development, with a number of smaller channels and two large entrances. Since it is open to visitation, this cave is constantly disturbed. The original cerrado vegetation that surrounds the three caves has been heavily deforested and replaced by pastures or degraded semi-deciduous forests (Bredt et al. 1999, Aguiar et al. 2014).

One or two nylon mist nets $(6 \times 3 \mathrm{~m})$ were used from $6 \mathrm{PM}$ to $6 \mathrm{AM}$ to capture the bats. After their capture, bats were marked, weighed and measured, their ectoparasites were removed, and then they were released. Nets were continuously checked to avoid the presence of too many bats at the same time in the net. We usually had one or two bats at the same time, but we avoided contact between the bats and the exchange of flies by removing the bats quickly for processing. Each bat removed from the mist net was kept in a separate cloth bag until processing to prevent the ectoparasites from escaping and to avoid sample contamination. All ectoparasites observed on the bats were removed with forceps and preserved in $70 \%$ ethanol. The species of bat flies were identified using the keys for Neotropical bat flies (Wenzel 1976, Guerrero 1993, 1994a,b, 1995a,b, 1996, 1998). Identification was confirmed by G. Graciolli and all vouchers of the ectoparasites species were deposited in the Chiroptera Collection at the University of Brasília (CCUNB).

\section{Data analysis}

The definitions of component community (the assemblage of parasite species on a given bat species), prevalence (the percentage of bats infected by a given parasite species) and the intensity of infection (the number of flies of a given species of bat) followed Bush et al. (1997). Confidence intervals were calculated 
Table 1. Number of Streblidae and bat species (N), number of infected hosts individuals (IH), prevalence (P) and mean intensity of infection (MI) with bat flies collected on phyllostomid bats in the Cafuringa Environmental Protection Area in the Cerrado of Central Brazil. * accidental

\begin{tabular}{|c|c|c|c|c|}
\hline Host $(\mathrm{N})$ and their streblid species & Streblidae $(\mathrm{N})$ & $\mathrm{IH}$ & $\mathrm{P}(\%)$ & MI \\
\hline \multicolumn{5}{|l|}{ Anoura caudifer (É. Geoffroy Saint-Hilaire) (3) } \\
\hline Anastrebla caudiferae Wenzel, 1976 & 1 & 1 & 33 & 1.0 \\
\hline Anastrebla modestini Wenzel, 1966 & 1 & 1 & 33 & 1.0 \\
\hline Strebla harderi Wenzel, 1976 & 1 & 1 & 33 & 1.0 \\
\hline Trichobius propinquus Wenzel, 1976 & 1 & 1 & 33 & 1.0 \\
\hline Trichobius tiptoni Wenzel, 1976 & 2 & 1 & 33 & 1.0 \\
\hline \multicolumn{5}{|l|}{ Carollia perspicillata (Linnaeus) (32) } \\
\hline Paraeuctenodes longipes* Pessoa et Guimaraes, 1937 & 1 & 1 & 3 & 1.0 \\
\hline Speiseria ambigua Kessel, 1925 & 3 & 2 & 6 & 1.0 \\
\hline Strebla guajiro (García et Casal, 1965) & 12 & 10 & 31 & 1.2 \\
\hline Trichobius dugesii Townsend, 1891 & 2 & 2 & 6 & 1.0 \\
\hline Trichobius joblingi Wenzel, 1966 & 93 & 28 & 91 & 3.3 \\
\hline Trichobius tiptoni & 3 & 1 & 3 & 3.0 \\
\hline Trichobius uniformis Curran, 1935 & 3 & 3 & 6 & 1.0 \\
\hline \multicolumn{5}{|l|}{ Chrotopterus auritus (W. Peters) (4) } \\
\hline Strebla chrotopteri Wenzel, 1976 & 11 & 4 & 75 & 3.7 \\
\hline Strebla mirabilis (Waterhouse, 1879) & 5 & 1 & 25 & 5.0 \\
\hline Trichobius longipes (Rudow, 1871) & 6 & 1 & 25 & 2.0 \\
\hline \multicolumn{5}{|l|}{ Desmodus rotundus (E. Geoffrey) (346) } \\
\hline Strebla mirabilis & 1 & 1 & 0.5 & 1.0 \\
\hline Strebla wiedemanni Kolenati, 1856 & 540 & 151 & 44 & 3.6 \\
\hline Trichobius furmani Wenzel, 1966 & 57 & 37 & 11 & 1.5 \\
\hline Trichobius parasiticus Gervais, 1844 & 214 & 102 & 30 & 2.1 \\
\hline \multicolumn{5}{|l|}{ Diaemus youngi (Jentik) (8) } \\
\hline Strebla diaemi Wenzel, 1966 & 51 & 8 & 100 & 6.4 \\
\hline Trichobius diaemi Wenzel, 1976 & 84 & 8 & 100 & 10.5 \\
\hline \multicolumn{5}{|l|}{ Diphylla ecaudata Spix (265) } \\
\hline Strebla mirabilis & 6 & 5 & 2 & 1.2 \\
\hline Strebla wiedemanni* & 4 & 3 & 1 & 1.3 \\
\hline Trichobius furmani & 372 & 114 & 43 & 3.3 \\
\hline Trichobius parasiticus & 9 & 4 & 2 & 2.2 \\
\hline Trichobius uniformis & 5 & 1 & 0.4 & 5.0 \\
\hline \multicolumn{5}{|l|}{ Glossophaga soricina (Pallas) (29) } \\
\hline Paraeuctenodes longipes & 10 & 5 & 17 & 2.0 \\
\hline Paratrichobius longicrus (Miranda-Ribeiro, 1907) & 3 & 2 & 7 & 1.5 \\
\hline Speiseria ambigua & 3 & 3 & 10 & 1.0 \\
\hline Strebla altmani Wenzel, 1966 & 2 & 1 & 6 & 1.0 \\
\hline Strebla guajiro & 5 & 5 & 17 & 1.0 \\
\hline Strebla mirabilis* & 1 & 1 & 3 & 1.0 \\
\hline Trichobius dugesii & 13 & 9 & 31 & 1.4 \\
\hline Trichobius furmani & 1 & 1 & 3 & 1.0 \\
\hline Trichobius joblingi & 11 & 8 & 24 & 1.7 \\
\hline Trichobius uniformis & 10 & 7 & 31 & 1.1 \\
\hline \multicolumn{5}{|l|}{ Lonchophylla dekeyseri Taddei, Vizotto et Sazima (38) } \\
\hline Speiseria ambigua & 11 & 8 & 21 & 1.2 \\
\hline Strebla altmani & 13 & 5 & 13 & 1.4 \\
\hline Strebla guajiro & 8 & 6 & 16 & 1.3 \\
\hline Trichobius dugesii & 4 & 1 & 3 & 4.0 \\
\hline Trichobius uniformis & 118 & 31 & 81 & 3.6 \\
\hline \multicolumn{5}{|l|}{ Lonchorhina aurita Tomes (3) } \\
\hline Trichobius dugesii & 1 & 1 & 33 & 1.0 \\
\hline Trichobius dugesioides Wenzel, 1966 & 18 & 3 & 100 & 6.0 \\
\hline \multicolumn{5}{|l|}{ Micronycteris minuta (Gervais) (1) } \\
\hline Trichobius joblingi & 3 & 1 & 100 & 3.0 \\
\hline \multicolumn{5}{|l|}{ Phyllostomus hastatus (Pallas) (12) } \\
\hline Strebla mirabilis & 10 & 4 & 33 & 2.5 \\
\hline Trichobius longipes & 32 & 9 & 83 & 3.2 \\
\hline \multicolumn{5}{|l|}{ Platyrrhinus lineatus (E. Geoffroy) (3) } \\
\hline Neotrichobius delicatus (Machado-Allison, 1966) & 1 & 1 & 33 & 1.0 \\
\hline Paratrichobius longicrus & 4 & 2 & 67 & 1.5 \\
\hline \multicolumn{5}{|l|}{ Sturnira lilium (E. Geoffroy) (1) } \\
\hline Megistopoda proxima (Seguy, 1926) & 5 & 1 & 100 & 2.0 \\
\hline \multicolumn{5}{|l|}{ Trachops cirrhosus (Spix) (7) } \\
\hline Trichobius dugesioides & 66 & 7 & 100 & 1.1 \\
\hline
\end{tabular}




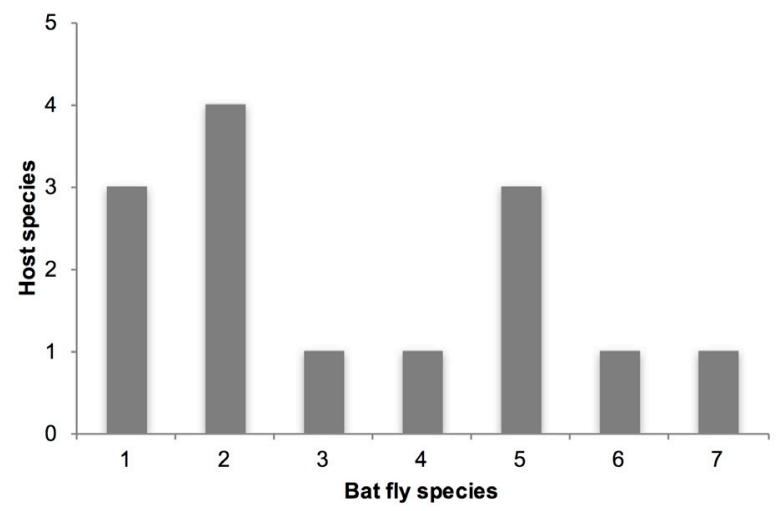

Fig. 2. Relation of the number of bat fly species on infected hosts, captured from April 2004 to March 2005 at the caves of Cafuringa Environmental Protection Area in the Federal District, Brazil.

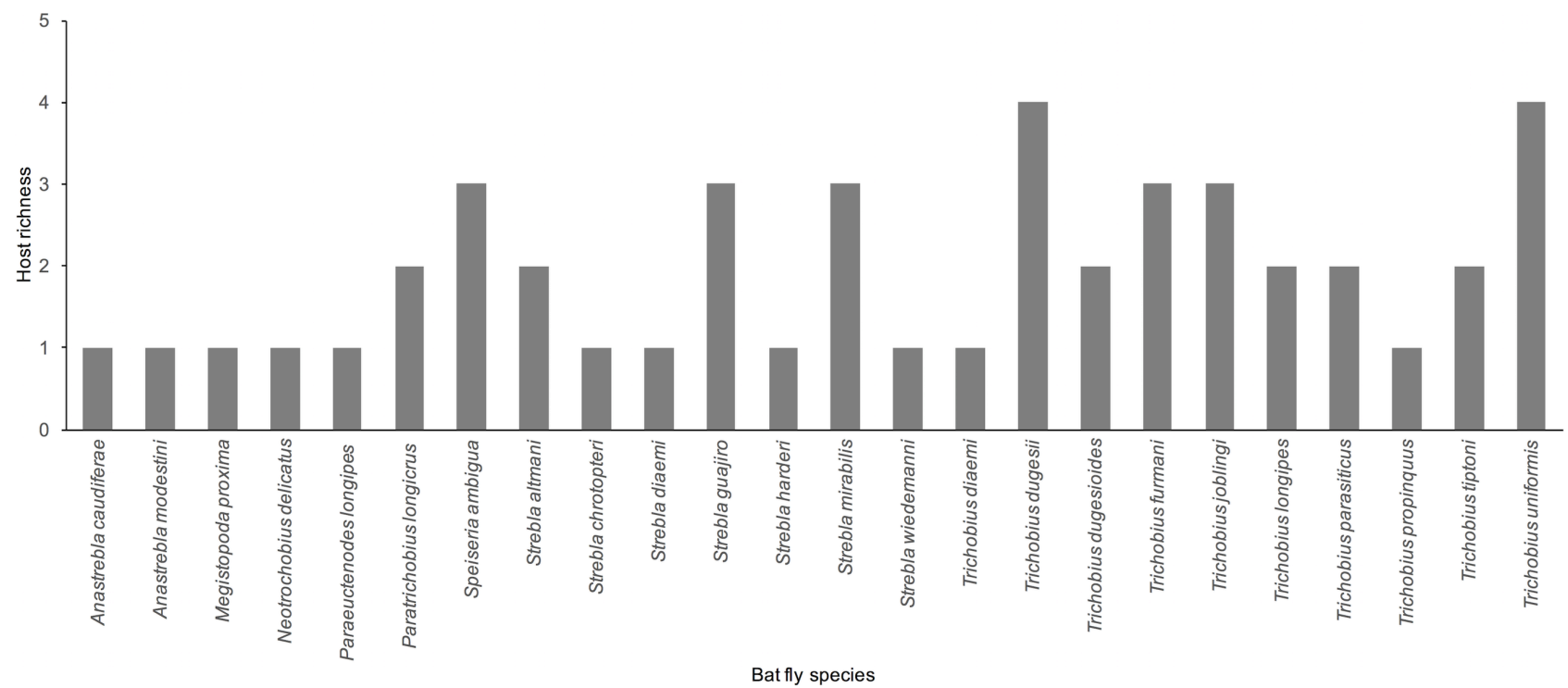

Fig. 3. Host richness of bat fly species on hosts captured from April 2004 to March 2005 at the caves of the Cafuringa Environmental Protection Area in the Federal District, Brazil (accidental records are not considered)..

using Quantitative Parasitology 3.0 (Rózsa et al. 2000). Non-primary infections (Dick 2007) were not considered to enable comparisons with other studies. Mean abundance refers to the number of ectoparasites per number of examined bats. Mean intensity refers to the average number of ectoparasites per number of infected bats. Host specificity was calculated using the Specificity Index (SI) (Marshall 1982). Since the data for ectoparasites had a non-normal distribution, we used a non-parametric analysis of variance (Kruskal-Wallis test) to gauge the preference of specific ectoparasites for a given species of bat host. The type of bat host was the categorical variable and the number of ectoparasites of each species was the continuous variable.

\section{RESULTS}

\section{Component community}

We captured 892 individuals bats from 15 species of Phyllostomidae and 752 of them (i.e. $84 \%$ of the captured bats) were infected with streblid ectoparasites. Only one bat species, Artibeus planirostris (Spix), was free of bat flies. The other bat species were parasitised by 24 species of streblids ( $\mathrm{n}=1841$ individuals) (Table 1). Among the captured bat flies, $11(46 \%)$ were monoxenous and 13 (54\%) were oligoxenous.

\section{Infracommunity}

Half of the bat species was infected by one or two bat fly species (Fig. 2). The species-richest infracommunities (all the ectoparasite species on an individual host, including accidental records) were on Glossophaga soricina (Pallas) (species $=10)$. Micronycteris minuta (Gervais), Sturnira lilium (E. Geoffroy) and Trachops cirrhosus (Spix) were each infected with only one streblid species; Diaemus youngi (Jentik), Lonchorhina aurita Tomes, Phyllostomus hastatus (Pallas) and Platyrrhinus lineatus (E. Geoffroy) were infected with two streblid species; Chrotopterus auritus (W. Peters) was infected with three species; Desmodus rotundus (E. Geoffroy) was infected with four streblid species and it was the most abundant bat species in this study site; Anoura caudifer (É. Geoffroy Saint-Hilaire), Diphylla ecaudata Spix and Lonchophylla dekeyseri Taddei, Vizotto et Sazima were infected with five streblid species each; and 
Table 2. Number of bats of the Phyllostomidae family, their infracommunities of ectoparasitic flies (N), and percentage of bats parasitized in the CEPA Cafuringa in the Cerrado of Central Brazil.

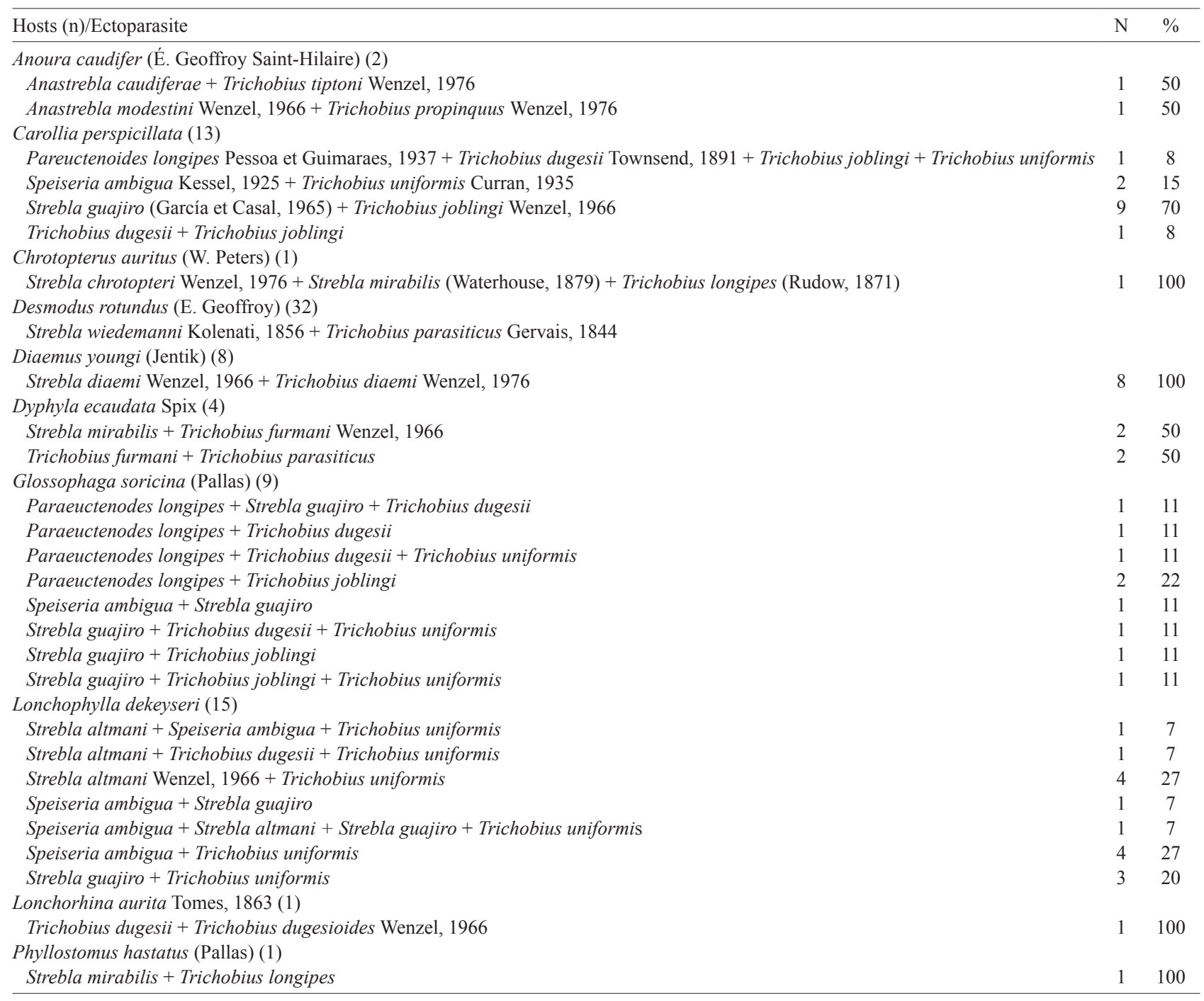

Carollia perspicillata (Linnaeus) was infected with seven streblid species.

\section{Prevalence}

Nine species of streblids bat fly species showed a prevalence higher than $50 \%$ (Table 1) as follows: Strebla diaemi Wenzel, 1966 (100\%) and Trichobius diaemi Wenzel, 1976 (100\%) on Diaemus youngi; Trichobius dugesioides Wenzel, 1966 (100\%) on Lonchorhina aurita and Trachops cirrhosus; Trichobius joblingi Wenzel, $1966(100 \%)$ on Micronycteris minuta and on C. perspicillata (91\%); Megistopoda proxima (Seguy, 1926) (100\%) on Sturnira lilium; Trichobius longipes Rudow, 1871 (83\%) on P. hastatus; Trichobius uniformis Curran, 1935 (81\%) on Lonchophylla dekeyseri; Strebla chrotopteri Wenzel, 1976 (75\%) on C. auritus and Paratrichobius longicrus (Miranda-Ribeiro, 1907) (67\%) on Platyrrhinus lineatus.

\section{Host specificity}

Abundance of streblid flies varied significantly among their bat hosts $\left(\mathrm{F}_{25}=206.9, \mathrm{p}<0.0001\right)$ (Fig. 3). The post hoc test results indicated that the differences observed were from the associations of Speria ambigua Kessel, 1925, Strebla guajiro (García et Casal, 1965), S. mirabilis (Waterhouse, 1879), Strebla wiedemanni Kolenati, 1856, Trichobius dugesii Townsend, 1891 and T. diaemi (Table 2).

Some bat fly species were more specific to their hosts than others, occurring in greater abundance on those preferred hosts (Fig. 3). For example, S. wiedemanni was found in high abundance $(\mathrm{n}=540)$, but only on a single host ( $S$. wiedemanni in D. ecaudata was considered accidental). Likewise, Trichobius furmani Wenzel, 1966 was also found in high abundance, but on two hosts only (D. ecaudata, $\mathrm{n}=372$ and $D$. rotundus, $\mathrm{n}=57$ ).

The bat species with the highest number of component communities of ectoparasites was $G$. soricina, with $44 \%$ of associations with three streblid species and also 55\% with two streblid species (Table 2). Regarding the ectoparasites, the species that had the highest numbers of non-accidental recorded associations were Trichobius dugesii, T. uniformis and Strebla mirabilis, which were found on four host species. 


\section{DISCUSSION}

The richness of bat flies found (15) was quite similar to the ones found at other sites in the same biome and at the same latitudes. For example, Eriksson et al. (2011) reported 17 species of bat flies in Serra da Bodoquena Park in the state of Mato Grosso do Sul, Graciolli et al. (2010) reported 21 species in Serranópolis in the state of Goiás, whereas Komeno and Linhares (1999) recorded 12 species in Uberlândia in the state of Minas Gerais. Nevertheless, the composition was quite different.

The composition of assemblage of streblid flies on bats from the Cerrado can be considered to be richer than expected. A total of 47 bat fly species have been reported in association with the 26 bat species in the Cerrado (Komeno and Linhares 1999, Graciolli et al. 2006, 2010, Aguiar and Antonini 2011, Eriksson et al. 2011, Santos et al. 2013). According to Santos et al. (2013), factors that may contribute to the high number of bat fly species in the Cerrado are external to the host and can affect the abundance of ectoparasites and their bats, favouring the sampling of host species with different component communities.

Additionally, it is possible to find bat fly species that are of low prevalence on their host species, such as those reported in deciduous forests (Camilotti et al. 2010) and the Caatinga (Rios et al. 2008), who presented a less rich and abundant fauna. Santos et al. (2013) listed were the vegetation structure, the abundance of host shelter and the high number of individuals and host species among the most important factors. Changes in the component communities of ectoparasitic flies on host species can also be attributed to regional differences in the species composition of bats, the biogeographic history of the area, as well as the lack of specificity of ectoparasites (Rui and Graciolli 2005).

Nonetheless, we cannot discard the possibility that trapping bats immediately outside caves at the emergence of evening with simultaneous bat captures of two or more bats may allow for the transference of flies from one host species to another. This contamination, while in the net before transference to individual cloth bags, could also account for the higher number of bat fly species found on bats in this study and the lower host specificity of the flies.

Only three accidental associations were recorded: Paraeuctenodes longipes Pessoa et Guimaraes, 1937 and T. uniformis on $C$. perspicillata and $S$. wiedemanni on D. ecaudata. Excluding these associations, we found the proportion of monoxenous species $(56 \%)$ to be lower than the $87 \%$ found by Dick and Gettinger (2005) and the $88 \%$ found by Santos et al. (2013). In contrast, we found a higher proportion of polyxenous species $(44 \%)$ compared to the proportions found in other studies. For example, Santos et al. (2013) found only one polyxenous species. Some of those species, however, presented a higher level of specificity to a few bat hosts.

This specificity appears to be very uncommon because bat species harbouring more than one fly species seem to be very common in the Neotropics and are reported in many areas of tropical forests (see Wenzel 1976, Bertola et al. 2005, Aguiar and Antonini 2011, Santos et al. 2013). However, as multiple bat species often roost in close as- sociation in caves, newly emerging flies may migrate to atypical hosts, widening the host range documented here for streblids. Therefore, we cannot be certain if we captured bats at the moment they were infected with newly emerging flies.

The taxonomic relationships of bat flies on Desmodus rotundus, Diaemus youngi and Diphylla ecaudata discussed here are similar to those reported by Aguiar and Antonini (2011) and are richer than those found in other regions of the Cerrado (Graciolli et al. 2010). A novelty in our study is that we found $T$. diaemi and $S$. diaemi on D. youngi and Trichobius furmani on D. rotundus. Graciolli et al. (2010) and Eriksson et al. (2011) found T. parasiticus Gervais, 1844 and also found only S. wiedemanni individuals on $D$. rotundus. Therefore, we have a new host record for these streblid flies in the Cerrado.

On the bat Lonchophylla dekeyseri, five non-transitory bat fly species were found. This is the first report of four bat fly species for L. dekeyseri in the Cerrado. Another paper describing bat flies on this host was that of Graciolli and Coelho (2001), who found only Trichobius lonchophyllae (Wenzel, 1966). It is worthwhile to stress that the data from Graciolli and Coelho (2001) originated from the same caves that we sampled ten years ago.

The $C$. perspicillata assemblage of bat fly richness in APA da Cafuringa was similar to what was found by Eriksson et al. (2011) in Serra da Bodoquena, Mato Grosso do Sul. We found that T. dugesii, T. tiptoni Wenzel, 1976 and T. uniformis are other non-transitory streblids that parasitise $C$. perspicillata in Brazil. In other localities within the Cerrado, $C$. perspicillata appears to be infected mainly with T. joblingi (Komeno and Linhares 1999, Eriksson et al. 2011, Santos et al. 2013). In reality, T. dugesii was first reported on G. soricina (see Graciolli et al. 2010, Eriksson et al. 2011), T. tiptoni on A. caudifer (Geoffroy Saint-Hilaire) (Komeno and Linhares 1999, Graciolli et al. 2010, Eriksson et al. 2011) and T. uniformis were found on Glossophaga soricina by Eriksson et al. (2011) and Graciolli and Dick (2012) and on D. ecaudata by Aguiar and Antonini (2011).

Whereas eight bat fly species were previously recorded on G. soricina, we found ten bat fly species. When compared with other studies that reported seven species (Eriksson et al. 2011), we found only three bat flies in common with our work. The non-transitory streblids recorded on G. soricina in our study site, Paraeuctenode longipes, Strebla guajiro and Paratrichobius longicrus (Miranda-Ribeiro, 1907), were not found in other localities of the Cerrado, indicating that they are new records. However, Trichobius dugesii and Speiseria ambigua are the same non-transitory species found in other localities in the Cerrado region (Graciolli and Coelho 2001, Graciolli et al. 2010).

Among the five non-vampire bat species that had more than three bat fly species, we found differences in the prevalence and intensity of infection, not only inside the assemblage but also in comparison with other areas within the Cerrado. On $A$. caudifer, a similar prevalence was found between the five species of bat fly (approximately 33\%) while Eriksson et al. (2011) found a prevalence of 20\% for T. tiptoni. 
For many bat fly species, a high prevalence was found, which was similar to the results obtained from other localities in the Cerrado. Strebla chrotopteri, for example, was the most prevalent on $C$. auritus $(75 \%)$, which is similar to the value found by Eriksson et al. (2011).

The prevalence of $T$. joblingi on $C$. perspicillata was higher $(91 \%)$ than those found in other regions of the Cerrado. A prevalence of $66 \%$ was found in Uberlândia (Komeno and Linhares 1999), whereas it was $41 \%$ in Serra da Bodoquena (Eriksson et al. 2011) and 55\% in Barreirinhas (Santos et al. 2013). A difference in prevalence from the associations between T. longipes and P. hastatus was also found in our study (83\%) in comparison with the 33\% recorded by Santos et al. (2013) in northeastern Brazil. The same trend was observed for $P$. longicrus and $P$. lineatus (67\%) compared to the $13 \%$ reported by Eriksson et al. (2011) in the Cerrado.

In our studied site, the prevalence of Megistopoda proxima (Seguy, 1926) on S. lilium (100\%) was higher than that found in other sites of the Cerrado region (Komeno and Linhares 1999, Eriksson et al. 2011). Thus, the prevalence of M. proxima on S. lilium appears to be more variable throughout the Atlantic Forest region than in the Cerrado region. This is not in accordance with the findings of Eriksson et al. (2011), who reported a similar per bat pattern of infection on S. lilium between sites in the Cerrado and Atlantic Forest regions.

The prevalence of streblids on G. soricina is usually low (Graciolli and Rui 2001, Bertola et al. 2005), similar to what we found in APA da Cafuringa $(<10 \%)$, except for P. longipes, S. guajiro and T. joblingi. According to Santos et al. (2013), this variation in values, observed from the study of different regions, supports the hypothesis that the distribution of streblids in different host populations is highly variable.

Overall comparisons of the available data suggest that the component community of streblids varies more be- tween the Cerrado and the Atlantic Forest phytogeographical regions than between sites within the same phytogeographical region. Therefore, environmental conditions play a vital role in local bat fly associations, which leads to a variable component community across a wide distribution of host species (Wenzel and Tipton 1966). Prevalence patterns vary extensively between sites, but there is no apparent pattern associated with phytogeographical domains. The local host abundance and shelter type are known to affect the prevalence of streblids (Arneberg et al. 1998).

In conclusion, bats roosting in caves are known to have both higher prevalence and intensity of infection relative to those roosting in more ephemeral situations (Patterson et al. 2007). Therefore, the data available on streblids support the hypothesis that conspecific bats use variable shelters throughout their distributional range and/or that bat species vary widely in their abundance within a phytogeographical region. However, the intensity of infection by streblids on a host species does not vary as much between sites and even between different phytogeographical regions. In the bats sampled by mist nets away from the roost, the generally higher prevalence and intensity of infection could result from the sampling of cave-inhabiting bats, rather than from their conspecific populations roosting in tree holes, leaves or other roost structures. Thus, additional studies at multiple sites are needed to verify the possible patterns of bat fly associations discussed in this study.

Acknowledgements. The bat captures were conducted under the license No. 10624 of SISBIO (System of Authorization and Information on Biodiversity) given to the first author. We thank the MMA/FNMA for the financial support related to this work. We also thank Gustavo Graciolli for the identification of ectoparasites species, and the two anonymous reviewers for critical comments on the paper. Yasmine Antonini received a scholarship from CNPq.

\section{REFERENCES}

Aguiar L.M.S., Antonini Y. 2011: Descriptive ecology of bat flies (Diptera: Hippoboscoidea) associated with vampire bats (Chiroptera: Phyllostomidae) in the cerrado of Central Brazil. Mem. Inst. Oswaldo Cruz 106: 170-176.

Aguiar L.M.S., Bernard E., Machado R.B. 2014: Habitat use and movements of Glossophaga soricina and Lonchophylla dekeyseri (Chiroptera: Phyllostomidae) in a Neotropical savannah. Zoologia 31: 223-229.

Alvares C.A., Stape J.L., Sentelhas P.C., De Moraes Gonçalves J.L., SparoveK G. 2013: Köppen's climate classification map for Brazil. Meteorol. Z. 22: 711-728.

Arneberg P., Skorping A., Grenfell B., Read A.F. 1998 Host densities as determinants of abundance in parasite communities. Proc. Biol. Sci. 265: 1283-1289.

Azevedo A.A., Linardi P.M. 2002: Streblidae (Diptera) of phyllostomid bats from Minas Gerais, Brazil. Mem. Inst. Oswaldo Cruz 97: 421-422.

Bernard E., Aguiar L.M.S., Machado R.B. 2011: Discovering the Brazilian bat fauna: a task for two centuries? Mamm. Rev. 41: 23-39.

Bertola P.B., Aires C.C., Favorito S.E., Graciolli G., AmAKU M., Rocha R.P. 2005: Bat flies (Diptera: Streblidae, Nycteribiidae) parasitic on bats (Mammalia: Chiroptera) at Parque
Estadual da Cantareira, São Paulo, Brazil: parasitism rates and host-parasite associations. Mem. Inst. Oswaldo Cruz 100: 25-32.

Bredt A., Uieda W., Magalhães E.D. 1999: Morcegos cavernícolas da região do Distrito Federal, centro-oeste do Brasil (Mammalia, Chiroptera). Rev. Bras. Zool. 16: 731-770.

Bush A.O., Lafferty K.D., Lotz J.M., Shostak A.W. 1997: Parasitology meets ecology on its own terms: Margolis et al. revisited. J. Parasitol. 83: 575-583.

Camilotti V., Graciolli G., Weber M., Arruda J., Cáceres N. 2010: Bat flies from the deciduous Atlantic Forest in southern Brazil: host-parasite relationships and parasitism rates. Acta Parasitol. 55: 194-200.

Coimbra J.C.E.A., Guimarães L.R., Mello D.A. 1984: Ocorrência de Streblidae (Diptera: Pupipara) em morcegos capturados em regiões de cerrado do Brasil Central. Rev. Bras. Entomol. 28: 547-550.

Dias P.A., Santos C.L.C., Rodrigues F.S., Rosa L.C., Lobato K.S., RebÊLo J.M.M. 2009: Espécies de moscas ectoparasitas (Diptera, Hippoboscoidea) de morcegos (Mammalia, Chiroptera) no estado do Maranhão. Rev. Bras. Entomol. 53: 128-133.

Dick C.W. 2007: High host specificity of obligate ectoparasites. Ecol. Entomol. 32: 446-450.

Dick C.W., Esberard C.E., Graciolli G., Bergallo H.G., Gettinger D. 2009: Assessing host specificity of obligate ec- 
toparasites in the absence of dispersal barriers. Parasitol. Res. 105: 1345-1349.

Dick C.W., GetTinger D. 2005: A faunal survey of Streblidae flies (Diptera: Streblidae) associated with bats in Paraguay. J. Parasitol. 91: 1015-1024.

Dick C.W., Patterson B.D. 2006: Bat flies: obligate ectoparasites of bats. In: S. Morand, B. Krasnov and R. Poulin (Eds.), Micromammals and Macroparasites: from Evolutionary Ecology to Management. Springer-Verlag, Tokyo, pp. 179-194.

Dittmar K., Porter M.L., Murray S., Whiting M.F. 2006: Molecular phylogenetic analysis of nycteribiid and streblid bat flies (Diptera: Brachycera, Calyptratae): implications for host associations and phylogeographic origins. Mol. Phylogenet. Evol. 38: $155-170$.

Eriksson A., Graciolli G., Fischer E. 2011: Bat flies on phyllostomid hosts in the Cerrado region: component community, prevalence and intensity of parasitism. Mem. Inst. Oswaldo Cruz 106: 274-278.

França D.S., Pereira S.N., Maas A.C.S., Martins M.A., Bolzan D.P., Lima I.P., Dias D., Peracchi A.L. 2013: Ectoparasitic flies (Diptera, Streblidae) of bats (Chiroptera, Phyllostomidae) in an Atlantic Forest area, southeastern Brazil. Braz. J. Biol. 73: 847-854.

Fritz G.N. 1983: Biology and ecology of bat flies (Diptera: Streblidae) on bats in the genus Carollia. J. Med. Entomol. 20: 1-10.

Graciolli G., Azevedo A.A. 2011: Ectoparasites of bats (Chiroptera, Furipteridae), with a description of a new species of Synthesiostrebla Townsend (Diptera, Streblidae) from Brazil. Rev. Bras. Entomol. 55: 501-504.

Graciolli G., Cáceres N.C., Bornschein M.R. 2006: Novos registros de moscas ectoparasitas (Diptera, Streblidae e Nycteribiidae) de morcegos (Mammalia, Chiroptera) em áreas de transição cerrado-floresta estacional no Mato Grosso do Sul, Brasil. Biota Neotropica 6: 1-4.

Graciolli G., Coelho D.C. 2001: Streblidae (Diptera, Hippoboscoidea) sobre morcegos filostomídeos (Chiroptera, Phyllostomidae) em cavernas do Distrito Federal Brasil. Revta. Bras. Zool 18: 965-970.

Graciolli G., Dick C.W. 2012: Description of a second species of Joblingia Dybas \& Wenzel, 1947 (Diptera: Streblidae). Syst. Parasitol. 81: 187-193.

Graciolli G., Rui A.M. 2001: Streblidae (Diptera, Hippoboscoidea) em morcegos (Chiroptera, Phyllostomidae) no nordeste do Rio Grande do Sul, Brasil. Iheringia 90: 85-90

Graciolli G., Zortéa M., Carvalho L.F.A.C. 2010: Bat flies (Diptera, Streblidae and Nycteribiidae) in a Cerrado area of Goiás State, Brazil. Rev. Bras. Entomol. 54: 511-514.

Guerrero R. 1993: Catalogo de los Streblidae (Diptera: Pupipara) parasitos de murcielagos (Mammalia: Chiroptera) del Nuevo Mundo. I. Clave para los generos y Nycterophiliinae. Acta Biol. Venez. 14: 61-75.

Guerrero R. 1994a: Catalogo de los Streblidae (Diptera: Pupipara) parasitos de murcielagos (Mammalia: Chiroptera) del Nuevo Mundo. II. Los grupos: pallidus, caecus, major, uniformis y longipes del genero Trichobius Gervais, 1844. Acta Biol. Venez. 15: $1-18$.

Guerrero R. 1994b: Catalogo de los Streblidae (Diptera: Pupipara) parasitos de murcielagos (Mammalia: Chiroptera) del Nuevo Mundo. IV. Trichobiinae com alas desarrolladas. Bol. Entomol. Venez. 9: 161-192.

Guerrero R. 1995a: Catalogo de los Streblidae (Diptera: Pupipara) parasitos de murcielagos (Mammalia: Chiroptera) del Nuevo Mundo. III. Los grupos: dugesii, dunni y phyllostomae del genero Trichobius Gervais, 1844. Acta Biol. Venez. 15: 1-27.
Guerrero R. 1995b: Catalogo de los Streblidae (Diptera: Pupipara) parasitos de murcielagos (Mammalia: Chiroptera) del Nuevo Mundo. V. Trichobiinae con alas reducidas o ausentes y miscelaneos. Bol. Entomol. Venez. 10: 135-160.

Guerrero R. 1996: Catalogo de los Streblidae (Diptera: Pupipara) parasitos de murcielagos (Mammalia: Chiroptera) del Nuevo Mundo. VI. Streblinae. Acta Biol. Venez. 16: 1-26.

Guerrero R. 1998: Notes on Neotropical batflies (Diptera, Streblidae). I. The genus Trichobius, with description of two new species and one new subspecies from Venezuela. Acta Parasitol. 43: 86-93.

Komeno C.A., Linhares A.X. 1999: Batflies parasitic on some phyllostomid bats in southeastern Brazil: parasitism rates and host-parasite relationships. Mem. Inst. Oswaldo Cruz 94: 151156.

Marshall A.J. 1982: Ecology of insects ectoparasitic on bats. In: T.H. Kunz (Ed.), Ecology of Bats. Springer, New York, pp. 369-401.

Patterson B.D., Dick C.W., Dittmar K. 2007: Roosting habits of bats affect their parasitism by bat flies (Diptera: Streblidae). J. Trop. Ecol. 23: 177-189.

Patterson B.D., Dick C.W., Dittmar K. 2008: Parasitism by bat flies (Diptera: Streblidae) on neotropical bats: effects of host body size, distribution, and abundance. Parasitol. Res. 103: 1091-1100.

Poulin R. 2007: Investing in attachment: evolution of anchoring structures in acanthocephalan parasites. Biol. J. Linn. Soc. 90: 637-645.

Rios G.F.P., SÁ-Neto R.J., Graciolli G. 2008: Fauna de dípteros parasitas de morcegos em uma área de Caatinga do nordeste do Brasil. Chiroptera Neotropical 14: 339-345.

Rózsa L., Reiczigel J., Majoros G. 2000: Quantifying parasites in samples of hosts. J. Parasitol. 86: 228-232

Rui A.M., Graciolli G. 2005: Moscas ectoparasitas (Diptera, Streblidae) de morcegos (Chiroptera, Phyllostomidae) no sul do Brasil: associações hospedeiros-parasitas e taxas de infestação. Rev. Bras. Zool. 22: 438-445.

Santos C.L., Pereira A.C., Bastos V.J.C., Graciolli G., ReBELO J.M. 2013: Parasitism of ectoparasitic flies on bats in the northern Brazilian cerrado. Acta Parasitol. 58: 207-214.

Ter Hofstede H.M., Fenton M.B. 2005: Relationships between roost preferences, ectoparasite density, and grooming behaviour of neotropical bats. J. Zool. 266: 333-340.

Ter Hofstede H.M., Fenton M.B., Whitaker J.J.O. 2004: Host and host-site specificity of bat flies (Diptera: Streblidae and Nycteribiidae) on Neotropical bats (Chiroptera). Can. J. Zool. 82: 616-626.

Wenzel R.L. 1976: The streblid bat flies of Venezuela (Diptera: Streblidae). Brigham Young University Sci. Bull., Biol. Series 20: $1-177$.

Wenzel R.L., Tipton V.J. 1966: Some relationships between mammal hosts and their ectoparasites. In: R.L. Wenzel and V. J. Tipton (Eds.), Ectoparasites of Panama, Field Museum of Natural History, Chicago, pp. 677-723.

Wenzel R.L., Tipton V.J., Kiewlicz A. 1966: The streblid bat flies of Panama (Diptera: Calyptera: Streblidae) In: R. L. Wenzel and V. J. Tipton (Eds.), Ectoparasites of Panama, Field Museum of Natural History, Chicago, pp. 405-675.

WHitAKER J.J.O. 1988: Collecting and preserving ectoparasites for ecological study. In: T.H. Kunz (Ed.), Ecological and Behavioral Methods for the Study of Bats. Smithsonian Institutions Press, Washington, pp. 459-474. 